\title{
Analisis Determinan Penghindaran Pajak Pada Perusahaan Manufaktur yang Terdaftar di Bursa Efek Indonesia
}

\author{
Mahendra Jaya Wardana ${ }^{1}$, Sartika Wulandari ${ }^{2}$ \\ ${ }^{1}$ Fakultas Ekonomika dan Bisnis Akuntansi, Universitas Stikubank Semarang \\ e-mail: mahendrajayaw@gmail.com \\ ${ }^{2}$ Fakultas Ekonomika dan Bisnis Akuntansi, Universitas Stikubank Semarang \\ e-mail: sartika_wulan@edu.unisbank.ac.id
}

\section{ARTICLE INFO}

Article history:

Received 30 September 2021

Received in revised form 2 November 2021

Accepted 10 November 2021

Available online 1 Desember 2021
ABSTRACT

The biggest source of state income from taxes. Indonesian government keep continuously increase the national income through taxes. The research examines how profitability, leverage, independent commissioners and the influence of institusional ownership. The sample used is manufacturing companies listed on the Indonesia Stock Exchange for the period 2017-2020. The sampling method uses purposive sampling in order to obtain 58 manufacturing companie. This study uses panel data regression analysis techniques with the help of the Eviews 10. This study shows that the independent variabel profitability has a significant positive effect on tax avoidance. While leverage, independent commissioners, and the influence of institusional ownership has no effect on tax avoidance,

Keywords: Penghindaran Pajak, Profitabilitas, Leverage, Komisaris Independen, Kepemilikan Institusional

\section{Pendahuluan}

Pajak merupakan pendapatan besar bagi suatu negara. Di negara Indonesia pajak sangatlah penting dalam pembangunan nasional demi terciptanya kesejahteraan bagi masyarakat Indonesia. Setiap tahunnya pemerintah selalu menganggarkan belanja rutin negara sehingga pemerintah mengharapkan wajib pajak agar taat membayar pajak sesuai dengan keadaan wajib pajak tersebut.

Bagi perusahaan pajak merupakan beban yang akan mengurangi laba bersih perusahaan hal tersebut tidak sesuai dengan tujuan perusahaan yaitu memperoleh laba semaksimal mungkin. Salah satu cara agar perusahaan tetap dapat memaksimalkan laba maka perusahaan melakukan praktik penghindaran pajak dan hal tersebut berlaku secara legal dengan tidak melanggar undangundang perpajakan. Praktik penghindaran pajak yang dilakukan perusahaan di Indonesia akan berdampak terhadap pendapatan negara. Hal ini didasari karena adanya perbedaan tujuan antara fiscus dengan perusahaan. dalam melakukan praktik penghindaran pajak. Salah satu cara yang dilakukan oleh perusahaan adalah dengan cara mengurangi laba perusahaan, dapat juga dengan menambahkan tingkat utang sehingga laba perusahaan menjadi sedikit yang menyebabkan beban pajak yang ditanggung perusahaan menjadi berkurang. 
Praktik penghindaran pajak di Indonesia sendiri membuat Indonesia kehilangan penerimaan pajak dalam jumlah yang besar, dalam laporan Tax Justice Network yang berjudul The State of Tax Justice 2020: Tax Justice in the Time of Covid-19 melaporkan bahwa akibat dari penghindaran pajak di Indonesia diperkirakan merugi hingga Rp. 68,7 triliun. Angka tersebut terdiri diantaranya merupakan buah dari penghindaran pajak korporasi di Indonesia sebesar Rp. 67,6 triliun, sedangkan sisanya sekitar Rp. 1,1 triliun berasal dari wajib pajak orang pribadi. Dalam praktiknya perusahaan multinasional mengalihkan laba sehingga laba yang akan di bayarkan lebih sedikit (Santoso, 2020) (Kontan.co.id).

Penghindaran pajak merupakan salah satu cara dalam menghindari pajak yang ditanggung perusahaan secara legal dan tidak melanggar undang-undang perpajakan dengan cara meminimalkan beban pajak (Arianandini \& Ramantha, 2018). Perusahaan meminimalkan beban pajak yaitu dengan cara memanfaatkan kelemahan-kelemahan yang ada didalam undang-undang perpajakan. Penghindaran pajak dapat menimbulkan beberapa risiko terhadap perusahaan yaitu bunga, kehilangan reputasi perusahaan, bunga sehingga dalam pengambilan keputusan penghindaran pajak perlu mempertimbangkannya (Yulyanah \& Kusumastuti, 2019). Dalam melakukan penghindaran pajak terdapat beberapa faktor yang mempengaruhi diantaranya yaitu profitabilitas, leverage, komisaris independen, kepemilikan institusional.

Profitabilitas merupakan suatu kemampuan perusahaan dalam mendapatkan laba pada suatu periode tertentu (Yulyanah \& Kusumastuti, 2019). Profitabilitas menggunakan alat ukur Return on asset (ROA) semakin tinggi profitabilitas semakin tinggi laba bersih perusahaan, maka kinerja suatu perusahaan semakin baik. Teori agensi mempengaruhi agen dalam mendaptkan laba yang maksimal pada perusahaan, semakin tinggi laba yang dihasilkan suatu perusahaan maka beban pajak yang di tanggu perusahaan tersebut semakin tinggi juga. (Anggraeni \& Oktaviani, 2021), (Yulyanah \& Kusumastuti, 2019), (Sari et al., 2020), (Irianto et al., 2017), dan (Mahdiana \& Amin, 2020) menyebutkan bahwa profitabilitas memiliki pengaruh positif terhadap penghindaran pajak. Berbeda dengan penelitian (V. R. Putri \& Putra, 2017), (Arianandini \& Ramantha, 2018), dan (Kimsen et al., 2019) menyebutkan bahwa profitabilitas berpengaruh negatif terhadap penghindaran pajak.

Leverage merupakan salah satu rasio keuangan yang menggambarkan hubungan tingkat hutang perusahaan dengan modal ataupun aset perusahaan (Mahdiana \& Amin, 2020). Rasio leverage digunakan untuk mengukur kemampuan perusahaan yang dibiayai dengan hutang. Leverage dapat mempengaruhi adanya praktik penghindaran pajak yang dilakukan oleh manajemen perusahaan. penambahan jumlah utang akan menjadikan beban bunga yang harus dibayarkan perusahaan menjadi kecil. Perusahaan menggunakan sumber utang dikarenakan beban bunga dapat mengurang beban pajak yang akan di tanggung suatu perusahaan. (Triyanti et al., 2020), (Mahdiana \& Amin, 2020), (Pratiwi et al., 2020), dan (Masrullah et al., 2018) menyebutkan bahwa leverage berpengaruh positif terhadap penghindaran pajak, sehingga tingkat utang perusahaan dapat mempengaruhi perusahaan dalam melakukan penghindaran pajak. Tetapi berbeda dengan penelitian (Yulyanah \& Kusumastuti, 2019) menyebutkan bahwa tingkat utang tidak berpengaruh terhadap penghindaran pajak.

Komisaris Independen merupakan anggota dewan komisaris yang tidak berhubungan dengan manajemen, dewan komisaris lain, dan juga dengan pemegang saham dalam perusahaan tersebut (Masrullah et al., 2018). Komisaris independen diukur dengan suatu presentase perbandingan antara komisaris independen dengan sejumlah anggota dewan komisaris yang memiiki perananan dalam melakukan pengawasan manajemen perusahaan. Komisaris independen yang ada di perusahaan apabila jumlahnya semakin banyak maka diharapakan perusahaan tidak akan melakukan praktik penghindaran pajak (Triyanti et al., 2020). Pada penelitian (Sari et al., 2020), (Eksandy, 2017) menyebutkan bahwa komisaris independen berpengaruh positif terhadap praktik penghindaran pajak. Sedangkan pada penelitian (Wijayanti \& Merkusiwati, 2017), (Amaliyah \& Rachmawati, 2019), (Pratomo \& Rana, 2021) menyebutkan bahwa komisaris independen berpengaruh negatif terhadap praktik penghindaran pajak. Sedangkan dalam

JURNAL ILMIAH KOMPUTERISASI AKUNTANSI Vol. 14, No. 2, Desember $2021: 297-307$ 
penelitian (Masrullah et al., 2018), dan (Triyanti et al., 2020) menyebutkan komisaris independent tidak berpengaruh terhadap penghindaran pajak.

Kepemilikan Institusonal merupakan kepemilikan saham oleh investor terhadap investasi yang dilakukan termasuk investasi saham (Darma et al., 2019). Struktur kepemilikan saham perusahaan dapat dibagi dalam dua kelompok yaitu saham milik institusi dan saham milik perorangan. Kepemilikan institusional diharapkan mampu untuk mengontrol kinerja manajemen dalam proses pengawasan secara efektif yaitu dengan cara saham yang di investasikan ke dalam perusahaan tersebut, apabila kinerja didalam perusahaan dirasa baik maka jumlah saham yang akan di investasikan kedalam perusahaan tersebut semakin banyak, karena investor menilai perusahaan tersebut memiliki dampak yang bagus terhadap para investor. Menurut penelitian (Yulyanah \& Kusumastuti, 2019), (Pratomo \& Rana, 2021), dan (Krisna, 2019) kepemilikan institusional berpengaruh negatif terhadap praktik penghindaran pajak. Sedangkan dalam penelitian (A. A. Putri \& Lawita, 2019), (V. R. Putri \& Putra, 2017) menyatakan dalam jurnalanya kepemilikan institusional berpengaruh positif terhadap praktik penghindaran pajak. Sedangkan dalam penelitian (Darma et al., 2019), (Arianandini \& Ramantha, 2018) menyebutkan bahwa kepemilikan institusional tidak berpengaruh terhadap penghindaran pajak.

Teori Agensi menurut (Jensen \& Meckling, 1976) merupakan hubungan keagenan seperti kontrak antara pemilik (principal) dan manajer (agen) yang bertujuan untuk menjalankan beberapa jasa mengenai kepentingan yang melibatkan pendelegasian beberapa wewenang pembuatan keputusan pada agen. Teori agensi dalam hubungannya dengan penghindaran pajak yaitu pemegang saham atau investor yang menginginkan manajemen untuk mengatur dan menguntungkan pemegang saham. Sehingga manajemen mengatur laba yang besar dengan beban pajak yang sedikit dalam upaya penghindaran pajak yang dilakukan oleh manajemen perusahaan. Konflik kepentingan biasa terjadi karena ketidakseimbangan informasi bahwa manajer memiliki informasi lebih dibandingakan dengan pemilik perusahaan (Anggraeni \& Oktaviani, 2021). Manajer melakukan penghindaran pajak agar laba yang dihasilkan perusahaan dapat maksimal sehingga manajer memperoleh citra yang baik didepan pemilik perusahaan. perbedaan konflik fiskus dengan manajer juga menimbulkan adanya pemanfaatan pajak dengan cara self assessment system dimana wajib pajak melaporkan wajib pajaknya sendiri.

Penghindaran pajak merupakan usaha penghematan pajak dengan memanfaatkan ketentuan pajak tanpa melanggar undang-undang perpajakan yang berlaku (Yulyanah \& Kusumastuti, 2019), Praktik penghindaran pajak yang dilakukan oleh perusahaan merupakan suatu kebijakan pemimpin perusahaan dalam pengambilan keputusan. Keputusan yang diambil berdasarkan dari kemampuan perusahaan. Praktik penghindaran pajak yang dilakukan oleh manajemen perusahaan akan menimbulkan terjadinya konflik agensi. Hal tersebut menimbulkan ketidakpatuhan yang dilakukan oleh perusahaan sehingga memiliki dampak terhadap penerimaan pajak negara (Mahdiana \& Amin, 2020). Dalam pengukuran Dalam pengukuran penghindaran pajak terdapat tiga pengukuranyaitu dengan menggunakan cash effective tax rate (CETR) yaitu dengan pembayaran pajak dibagi dengan laba sebelum pajak. Pengukuran kedua penghindaran pajak yaitu dengan effective tax rate (ETR) yaitu dengan cara membagi beban pajak dengan laba sebelum pajak. Pengukuran penghindaran pajak yang ketiga yaitu dengan book-tax differences (BTD) dengan cara mengukur besarnya perbedaan laba akuntasi dengan laba fiskal yaitu laba akuntansi-laba fiskal dibagi dengan total asset (Hanlon \& Heitzman, 2010). Didalam penelitian ini menggunakan pengukuran book-tax differences (BTD).

Profitabilitas dianggap sebagai indikator dalam pengukuran sebuah kinerja internal perusahaan didalam mengelola laba perusaahan yang dihasilkan pada periode tersebut. Rasio profitabiltas yang tinggi dapat menunjukkan bahwa perusahaan tersebut mampu menghasilkan laba yang maksimal. Apabila suatu perusahaan memiliki laba yang tinggi maka beban pajak yang akan di tanggung perusahaan tersebut tinggi juga. Hal ini menyebabkan terjadinya penghindaran

Analisis Determinan Penghindaran Pajak Pada Perusahaan Manufaktur yang Terdaftar di Bursa Efek Indonesia (Mahendra Jaya Wardana) 
pajak oleh suatu perusaahn tersebut (Yulyanah \& Kusumastuti, 2019). Profitabilitas dapat dikur dengan menggunakan berbagai rasio keuangan, salah satunya yaitu Return on Asset (ROA). ROA merupakan rasio yang mengukur dengan membandingkan laba bersih dengan total aset. Semakin tinggi tingkat keuntungan maka semakin efektif perusahaan tersebut dalam mengelola aset perusahaan (Anggraeni \& Oktaviani, 2021). Profitabilitas dapat mempengaruhi penghindaran pajak suatu perusahaan karena dianggap sebagai salah satu bentuk indikator kinerja manajemen dalam mengelola laba perusahaan. Agenchy Theory juga dapat memacu para agen dalam meningkatkan laba suatu perusahaan sehingga jumlah pajak yang dihasilkan akan meningkat seiring dengan laba yang tinggi. Hal ini yang menyebabkan perusahaan untuk melakukan penghindaran pajak. (Yulyanah \& Kusumastuti, 2019), (Anggraeni \& Oktaviani, 2021), (Sari et al., 2020), dan (Mahdiana \& Amin, 2020) menyatakan bahwa tingkat profitabilitas berpengaruh positif terhadap terhadap penghindaran pajak

Leverage merupakan suatu rasio tingkat hutang yang menggambarkan hubungan antara hutang terhadap modal atau aset perusahaan. Rasio leverage menunjukkan sumber dana operasional perusahaan. sehingga leverage dapat juga menjadi salah satu cara perusahaan dalam melakukan penghindaran pajak. Semakin tinggi tingkat hutang pada perusahaan tersebut dalam membiayai modal atau asetnya maka dapat dikatakan perusahaan tersebut akan membayarkan beban bunga yang tinggi. Sehingga leverage yang timbul atas utang tersebut akan menjadi pengurang laba bersih suatu perusahaan (Mahdiana \& Amin, 2020) Rasio leverage menggunakan pengukuran yaitu debt to equity ratio dengan melihat tingkat hutang dibagi dengan modal perusahaan. Tingkat utang suatu perusahaan digunakana sebagai alat untuk membeli atau membiayai aset perusahaan. Rasio leverage dapat mengukur seberapa besar pengaruh tingkat utang dalam membiayai aktivitas suatu perusahaan. dalam penelitian (Triyanti et al., 2020), (Mahdiana \& Amin, 2020), (Pratiwi et al., 2020), dan (Masrullah et al., 2018) menyatakan bahwa leverage berpengaruh positif terhadap penghindaran pajak. Tingkat hutang yang di hasilkan perusahaan akan menjadikan beban bunga yang akan dibayarkan perusahaan menjadi tinggi.

Komisaris Independen merupakan anggota dewan komisaris yang bukan berasal dari dalam perusahaan sehingga dianggap memiliki resiko penghindaran pajak yang rendah didalam perusahaan tersebut (Darma et al., 2019). Komisaris independen didalam suatu perusahaan tidak boleh memiliki hubungan pribadi dengan pemegang saham maupun jajaran direksi. Komisaris independent diharapkan dapat berkontribusi terhadap hasil akhir laporan keuangan yang bermutu dan terlepasa dari praktik penghindaran pajak. Komisaris independen adalah dewan komisaris yang berasal dari luar perusahaan. Dengan adanya komisaris independent yang banyak maka diharapkan dalam melakukan pengawasan terhadap manajemen akan semakin ketat. Sehingga secara tidak langsung presentase dewan komisaris pada suatu perusahaan secara tidak langsung dapat mempengaruhi manajemen perusahaan. Pada penelitian (Wijayanti \& Merkusiwati, 2017), (Amaliyah \& Rachmawati, 2019), dan (Pratomo \& Rana, 2021) menyatakan bahwa komisaris independen berpengaruh negatif terhadap penghindaran pajak.

Kepemilikan Institusional adalah lembaga yang memiliki pengaruh yang besar didalam investasi saham perusahaan. Sehingga biasanya institusi menyerahkan tanggung jawab dalam mengelola investasi perusahaan (Sari et al., 2020). Kepemilikan intitusional memiliki keududukan yag tinggi didalam perusahaan dalam mengawasi agar tingkat terjadinya praktik penghindaran pajak menjadi kecil. Kepemilikan institusional juga berpengaruh terhadap pengambilan keputusan perusahaan. Kepemilikan institusional adalah jumlah saham yang dimiliki institusi lain baik itu pemerintah maupun swasta. Kepemilikan institusional diharapkan dapat mengontrol manajemen didalam proses pengawasan. Pengukuran kepemilikan institusional yaitu dengan cara presentasi jumlah saham pemegang saham instusi dari jumlah saham yang beredar. Kepemilikan institusional berperan penting dalam perusahaan apabila tingkat kepemilikan institusional tinggi maka semakin cenderung dalam meminimalisir pelaporan perpajakannya. Dalam penelitian (Yulyanah \& Kusumastuti, 2019), (Pratomo \& Rana, 2021), dan (Krisna, 2019).

JURNAL ILMIAH KOMPUTERISASI AKUNTANSI Vol. 14, No. 2, Desember $2021: 297-307$ 
Berdasarkan research gap yang telah dijelaskan, penelitian dilakukan untuk mengetahui pengaruh profitabilitas, leverage, komisaris independent, dan kepemilikan institusional terhadap penghindaran pajak. Kerangka pemikiran ditunjukkan dalam gambar sebagai berikut:

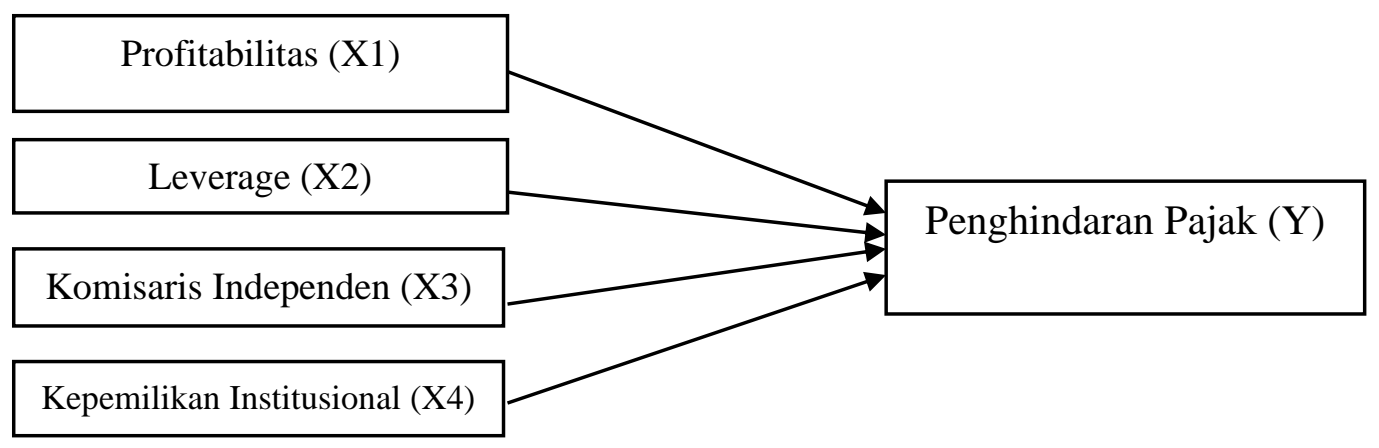

\section{Gambar 1 Kerangka Penelitian}

Hipotesis merupakan jawaban sementara terhadap permasalahan dalam suatu penelitian. Hipotesis yang diuji dalam penelitian ini adalah:

H1 : Profitabilitas diduga berpengaruh positif terhadap Penghindaran Pajak

$\mathrm{H} 2$ : Leverage diduga berpengaruh positif terhadap Penghindaran Pajak

H3 : Komisaris Indepeneden diduga berpengaruh negatif terhadap penghindaran pajak

H4 : Kepemilikan Institusional diduga berpengaruh negatif terhadap penghindaran pajak

\section{Metode Penelitian}

Pada penelitian ini menggunakan variabel dependen dan varibel independen. Variabel dependen (Y) adalah variabel yang memberikan reaksi jika dihubungkan dengan variabel bebas atau nilainya dipengaruhi oleh variabel independen. Sedangakan variabel Independen adalah variabel yang mempengaruhi sebab perubahan variabel dependen. Variabel dependen pada penelitian ini adalah penghindaran pajak sedangkan untuk variabel independennya yaitu profitabilitas, leverage, komisaris independen, dan kepemilikan institusional. Variabel-variabel yang digunakan dalam penelitian ini adalah sebagai berikut:

Penghindaran pajak merupakan strategi yang dilakukan suatu wajib pajak yaitu perusahaan dalam mengurangi atau menghindari pajak secara legal (Yulyanah \& Kusumastuti, 2019). Proksi yang digunakan dalam mengukur penghindaran pajak adalah Total Boox Tax Defference (BTD).

$$
\text { BTD }=\frac{\text { Laba Komersial Sebelum Pajak-Laba Fiskal }}{\text { Total Aset }}
$$

Profitabilitas merupakan salah satu faktor yang berpengaruh terhadap penghindaran pajak (Sari et al., 2020). Proksi yang digunakan dalam penelitian ini untuk mengukur profitabilitas adalah menggunakan Return on Asset (ROA)

$$
\text { ROA }=\frac{\text { Laba Setelah Pajak }}{\text { Total Aset }}
$$

Leverage merupakan rasio untuk mengukur kemampuan suatu perusahaan utang jangka panjang maupun jangka pendek (Yulyanah \& Kusumastuti, 2019). Proksi yang digunakan dalam penelitian ini menggunakan Debt to Equity Ratio.

$$
\text { DER }=\frac{\text { Total Liabilities }}{\text { Total Equity }}
$$

Komisaris Independen merupakan anggota dewan komisaris yang berasal dari luar perusahaan yang dianggap memiliki risiko kecil, sehingga dalam praktik penghindaran pajak komisaris independen diharapkan dapat mengurangi adanya praktik penghindaran pajak.

$$
\text { Komisaris Independen }=\frac{\text { Tumlah Komisaris Independen }}{\text { Tumlah Seluruh Dewan Komisaris }}
$$


Kepemilikan institusional merupakan prosentase saham yang dimiliki oleh investor instutusional seperti pemerintah, perusahaan asuransi, perbankan, jamsostek, dana pensiun (Yulyanah \& Kusumastuti, 2019)

$$
\text { Kepemilikan Institusional }=\frac{\text { Saham yang dimilikj institusional }}{\text { Tumlah saham yang beredar }}
$$

\section{Objek Penelitian, Unit Sampel, Populasi, dan Penentuan Sampel}

Pada penelitian ini populasi yang diambil merupakan perusahaan manufaktur yang terdaftar di Bursa Efek Indonesia selama periode 2017-2020. Teknik sampling yang digunakan pada penelitian ini adalah purposive sampling methode yaitu sejumlah sampel yang dipilih dari populasi dengan menggunakan pertimbangan kriteria tertentu serta sesuai dengan tujuan penelitian. Kriteria sampel dalam penelitian ini yaitu (1) perusahaan manufaktur yang terdaftar di Bursa Efek Indonesia Periode 2017-2020. (2) perusahaan Manufaktur yang menerbitkan laporan keuangan pada periode 2017-2020 secara berturut-turut. (3) perusahaan manufaktur yang mengalami laba tahun berjalan dan juga mengalami laba fiskal selama periode 2017-2020 berturut-turut.

\section{Hasil dan Pembahasan}

Populasi dalam penelitian ini adalah perusahaan manufaktur yang terdaftar di Bursa Efek Indonesia selama periode 2017-2020. Pemilihan sampel menggunaan teknik purposive sampling dengan kriteria sebagai berikut:

Tabel 1. Kriteria Sampel

\begin{tabular}{|l|c|}
\hline $\begin{array}{l}\text { Jumlah Perusahaan Manufaktur yang terdaftar di BEI selama Periode 2017- } \\
2020\end{array}$ & 149 \\
\hline Pengurangan Sampel Kriteria 1 & $(4)$ \\
\hline Perusahaan Manufaktur Yang Tidak Menerbitka LK Secara Berturut-turut & (85) \\
\hline Pengurangan Sampel Kriteria 2 & \\
\hline $\begin{array}{l}\text { Perusahaan Manufaktur Yang Tidak Memiliki Laba Tahun Berjalan Dan } \\
\text { Tidak Memiliki Laba Fiskal }\end{array}$ & $(2)$ \\
\hline Pengurangan Sampel Kriteria 3 & \\
\hline $\begin{array}{l}\text { Perusahaan Manufaktur Yang Tidak Memiliki Informasi Kepemilkan } \\
\text { Institusional }\end{array}$ & $\mathbf{5 8}$ \\
\hline \multicolumn{2}{|l|}{} \\
\hline
\end{tabular}

\section{Teknik Analisis}

Teknik analisis yang digunakan berupa analisis data panel. Pengujian data panel dapat dilakukan dengan tiga estimasi regresi data panel yaitu Common Effect Model, Fixed Effect Model dan Random Effect Model. Dalam memilih model mana yang terbaik dalam penelitian ini maka diperlukan uji sebagai berikut:

Tabel 2. Uji Chow

Redundant Fixed Effects Tests

Pool: Untitled

Test cross-section fixed effects

\begin{tabular}{lrrr}
\hline \hline Effects Test & Statistic & d.f. & Prob. \\
\hline \hline Cross-section F & 3.037239 & $(57,170)$ & 0.0000 \\
Cross-section Chi-square & 162.931143 & 57 & 0.0000
\end{tabular}

JURNAL ILMIAH KOMPUTERISASI AKUNTANSI Vol. 14, No. 2, Desember $2021: 297-307$ 
Uji Chow bertujuan untuk menentukan model analisis data yang akan digunakan dalam penelitian ini. Uji chow bertujuan untuk menentukan common effect model (CEM) dengan fixed effect model (FEM). Dalam Tabel 1 Uji Chow menunjukkan nilai probabilitas pada F-test sebsesar 0,0000 dan Chi-square sebesar 0,0000 yang memiliki nilai lebih kecil dari 0,05 drhingga dapat disimpulkan bahwa model terbaik yang dapat digunakan dalam penelitian ini adalah fixed effect model (FEM).

Tabel 2. Uji Hausman

Correlated Random Effects - Hausman Test

Pool: Untitled

Test cross-section random effects

\begin{tabular}{|c|c|c|c|}
\hline Test Summary & $\begin{array}{l}\text { Chi-Sq. } \\
\text { Statistic }\end{array}$ & Chi-Sq. d.f. & Prob. \\
\hline Cross-section random & 3.864909 & 4 & 0.4246 \\
\hline
\end{tabular}

Uji Hausman bertujuan untuk mengetahui model terbaik apa yang digunakan antara fixed effect model (FEM) dengan random effect Model (REM). Hasil uji pada hausman pada tabel uji hausman menunjukkan bahwa probabilitas pada Cross-section random sebesar 0,4246 yang lebih besar dari 0,05 sehingga dari hasil uji yang terdapat pada tabel uji hausman dapat disimpulkan bahwa model terbaik yang dapat digunakan adalah random effect model (REM).

\section{Uji Statistik Deskriptif}

Berdasarkan hasil uji statistika deskriptif dapat disimpulkan bahwa:

Tabel 2. Hasil uji statistik deskriptif

$\begin{array}{lccccc} & \text { BTD? } & \text { ROA? } & \text { DER? } & \text { KI? } & \text { KPI? } \\ \text { Mean } & 0.042947 & 0.096623 & 0.688929 & 0.408358 & 0.679172 \\ \text { Median } & 0.022100 & 0.066700 & 0.511150 & 0.400000 & 0.755100 \\ \text { Maximum } & 0.683000 & 0.921000 & 3.609300 & 0.666700 & 0.997100 \\ \text { Minimum } & -0.045000 & 0.000500 & 0.031200 & 0.166700 & 0.014800 \\ \text { Std. Dev. } & 0.063752 & 0.107325 & 0.617999 & 0.096812 & 0.237767 \\ \text { Skewness } & 4.948694 & 3.743846 & 2.166964 & 0.343844 & -1.282307 \\ \text { Kurtosis } & 45.71088 & 23.20293 & 8.906992 & 2.772865 & 4.203511 \\ & & & & & \\ \text { Jarque-Bera } & 18581.05 & 4487.497 & 518.8631 & 5.070212 & 77.58159 \\ \text { Probability } & 0.000000 & 0.000000 & 0.000000 & 0.079253 & 0.000000 \\ & & & & & \\ \text { Sum } & 9.963800 & 22.41650 & 159.8315 & 94.73910 & 157.5679 \\ \text { Sum Sq. Dev. } & 0.938850 & 2.660796 & 88.22410 & 2.165062 & 13.05918 \\ & & & & & \\ \text { Observations } & 232 & 232 & 232 & 232 & 232 \\ \text { Cross sections } & 58 & 58 & 58 & 58 & 58\end{array}$

Sumber: Olah data eviews 10

Penghindaran Pajak. Nilai BTD objek penelitian bervariasi dengan nilai minimum BTD 0,0450; PT Argha Karya Prma Industry Tbk pada tahun 2019, nilai maksimum BTD 0,6830; PT Mlti Prima Sejahtera Tbk pada tahun 2017. 
Profitabilitas. Nilai ROA objek penelitian minimum 0,0005; PT Sekar Bumi Tbk pada tahun 2019, sedangkan nilai maksimum 0,9210; PT Merck pada tahun 2018.

Leverage. Nilai minimum pada leverage sebesar 0,0312; PT Sariguna Primatirta Tbk pada tahun 2018, sedangkan untuk nilai maksimum 3,6093; PT Indah Aluminium Industry Tbk pada tahun 2018.

Komisaris Independen. Nilai minimum komisaris independen yaitu 0,1667; PT Unilever Indonesia Tbk pada tahun 2020, sedangkan untuk nilai maksimum 0,6667; PT H.M. Sampoerna Tbk pada tahun 2017.

Kepemilikan Institusional. Nilai minimum kepemilikan institusional yaitu 0,0148; PT Campina Ice Cream Industry Tbk pada tahun 2017-2020, sedangkan untuk nilai maksimum sebesar 0,9971; PT Fajar Surya Wisesa Tbk pada tahun 2019.

Tabel 5. Hasil dari REM

\begin{tabular}{crrrr}
\hline \hline Variable & Coefficient & Std. Error & t-Statistic & Prob. \\
\hline \hline C & -0.035677 & 0.069503 & -0.513313 & 0.6084 \\
ROA? & 0.301978 & 0.046354 & 6.514565 & 0.0000 \\
DER? & 0.014448 & 0.015175 & 0.952052 & 0.3424 \\
KI? & 0.001233 & 0.060921 & 0.020237 & 0.9839 \\
KPI? & 0.057408 & 0.090736 & 0.632688 & 0.5278 \\
\hline \hline & Sumber: Olah data eviews & $=$ & &
\end{tabular}

Hasil analisis menunjukan hasil signifikansi yang dihasilkan oleh profitabilitas $0,000<$ 0,05 dengan nilai koefisien sebesar 0,301 .

Tabel 6. Hasil Koefisien Determinan

Cross-section fixed (dummy variables)

\begin{tabular}{lllr}
\hline \hline R-squared & 0.606428 & Mean dependent var & 0.042947 \\
Adjusted R-squared & 0.465204 & S.D. dependent var & 0.063752 \\
S.E. of regression & 0.046621 & Akaike info criterion & -3.069967 \\
Sum squared resid & 0.369506 & Schwarz criterion & -2.148856 \\
Log likelihood & 418.1162 & Hannan-Quinn criter. & -2.698493 \\
F-statistic & 4.294111 & Durbin-Watson stat & 2.040672 \\
Prob(F-statistic) & 0.000000 & & \\
\hline
\end{tabular}

Hasil olah data menunjukan $\mathrm{F}$ - statistic sebesar 4,2941 dan tingkat signifikan sebesar $0,000<0,05$. Hal ini berarti profitabilitas, leverage, komisaris independent, kepemilikan institusional secara simultan berpengaruh terhadap penghindaran pajak. Diketahui nilai koefisien determinasi sebesar 0,465 atau $4,65 \%$. Artinya variabel profitabilitas, leverage, komisaris independent, kepemilikan institusional mampu menjelaskan pengaruhnya terhadap penghindaran pajak sebesar 4,7\% dan sisanya 95,3 dipengaruhi oleh variabel lain diluar variabel penelitian.

\section{Pengaruh profitabilitas terhadap penghindaran pajak}

Berdasarkan hasil pengujin olah data panel menunjukan bahwa hasil koefisien regresi $\mathrm{X}_{1}$ yaitu 0,272672 yang memiliki nilai positif dengan probabilitasnya 0,0000 yang berarti bahwa nilai probabilitasnya $0,0000<0,05$. Hasil tersebut menunjukan profitabilitas berpengaruh positif terhadap penghindaran pajak pada perusahaan manufaktur dalam periode 2017-2020 yang terdaftar di Bursa Efek Indonesia. Hal ini menunjukkan $\mathrm{H}_{1}$ diterima. Semakin tinggi rasio ringkat keuntungan semakin tinggi juga resiko perusahaan dalam melakukan praktik penghindaran pajak. Apabila didalam perusahaan memiliki laba yang besar maka beban pajak yang akan dibayarkan menjadi besar, sehingga dapat memungkinkan untuk manajer melakukan praktik penghindaran

JURNAL ILMIAH KOMPUTERISASI AKUNTANSI Vol. 14, No. 2, Desember $2021: 297-307$ 
pajak. Sehingga laba yang di hasilkan perusahaan menjadi maksimal dan pajak yang harus dibayarkan menjadi berkurang. Hasil penelitian ini sejalan dengan penelitian (Anggraeni \& Oktaviani, 2021), (Yulyanah \& Kusumastuti, 2019), (Sari et al., 2020), dan (Irianto et al., 2017) yang menyatakan bahwa profitabilitas berpengaruh terhadap penghindaran pajak. Namun, berbeda dengan penelitian (Arianandini \& Ramantha, 2018) yang menyatakan bahwa profitabilitas berpengaruh negatif terhadap penghindaran pajak.

\section{Pengaruh leverage terhadap penghindaran pajak}

Berdasarkan hasil pengujian olah data panel menunjukan bahwa hasil koefisien regresi $\mathrm{X}_{2}$ yaitu $-0,005759$ yang memiliki nilai negative dengan probabilitasnya 0,4749 yang berarti bahwa nilai probabilitasnya $0,4749>0,05$. Hasil tersebut menunjukan bahwa leverage tidak berpengaruh terhadap penghindaran pajak. Hal ini menunjukkan bahwa $\mathrm{H}_{2}$ ditolak. Hal ini dikarenakan perusahaan memiliki rasio leverage rendah sehingga tidak memiliki pengaruh terhadap praktik penghindaran pajak. Hasil penelitian ini sejalan dengan penelitian (Yulyanah \& Kusumastuti, 2019), (Sari et al., 2020), dan (Arianandini \& Ramantha, 2018) yang menyatakan bahwa leverage atau tingkat utang tidak berpengaruh terhadap penghindaran pajak. Namun, berbeda dengan penelitian (Irianto et al., 2017) yang menyebutkan bahwa leverage atau tingkat utang berpengaruh negatif terhadap penghindaran pajak.

\section{Pengaruh komisaris independen terhadap penghindaran pajak}

Berdasarkan hasil pengujian olah data panel menunjukan bahwa hasil koefisien regresi $\mathrm{X}_{3}$ yaitu 0,022892 yang memiliki nilai positif dengan probabilitasnya 0,6141 yang berarti bahwa nilai probabilitasnya $0,6141>0,05$. Hasil tersebut menunjukan bahwa komisaris independen tidak berpengaruh terhadap penghindaran pajak.Hal ini menunjukkan bahwa $\mathrm{H}_{3}$ ditolak. Hal ini membuktikan bahwa proporsi dewan komisaris independent tidak berpengaruh terhadap prraktik penghindaran pajak. Disis lain tidak semua dewan komisaris independent menunjukkan independensinya sehingga mengakibatkan adanya fungsi pengawasan yang tidak maksimal. Hasil penelitian ini sejalan dengan penelitian (Darma et al., 2019) dan (Triyanti et al., 2020) yang menyatakan bahwa komisaris independen tidak berpengaruh terhadap penghindaran pajak. Namun menurut penelitian (Sari et al., 2020) menyatakan bahwa komisaris independen berpengaruh positif terhadap penghindaran pajak.

\section{Pengaruh kepemilikan institusional terhadap penghindaran pajak}

Berdasarkan hasil pengujian olah data panel menunjukan bahwa hasil koefisien regresi $\mathrm{X}_{4}$ yaitu - 0,013119 yang memiliki nilai negative dengan probabilitasnya 0,5639 yang berarti bahwa nilai probabilitasnya $0,5639>0,05$. Hasil tersebut menunjukan bahwa kepemilikan institusional tidak berpengaruh terhadap penghindaran pajak. Hal ini menunjukkan bahwa $\mathrm{H}_{4}$ ditolak. Hal ini dikarenakan didalam perusahaan memiliki kepemilikan saham institusional yang tinggi sehingga memiliki sumber daya yang lebih sehingga dalam melakukan pengawasan yang baik akan menjadikan tindakan manajemen menjadi baik juga. Hasil penelitian ini sejalan dengan penelitian (Darma et al., 2019), (Sari et al., 2020), dan (Arianandini \& Ramantha, 2018) yang menyatakan bahwa kepemilikan institusional tidak berpengaruh terhadap penghindaran pajak. Sedangkan menurut penelitian (Yulyanah \& Kusumastuti, 2019) kepemilikan institusional berpengaruh negatif terhadap penghindaran pajak.

\section{Kesimpulan}

Dari hasil pengujian yang telah dilakukan dalam penelitian ini, dengan menguji faktorfaktor yang mempengaruhi penghindaran pajak. dapat disimpulkan bahwa:

1. Profitabilitas berpengarus positif terhadap penghindaran pajak,

2. Leverage tidak berpengaruh terhadap penghindaran pajak 
3. Komisaris Independen tidak berpengaruh terhadap penghindaran pajak

4. Kepemilikan Institusional tidak berpengaruh terhadap penghindaran pajak.

Berdasarkan hasil analisis pembahasan serta beberapa kesimpulan pada peneliti ini adapun saran-saran yang dapat diberikan melalui hasil penelitian ini agar mendapatkan hasil yang baik maka diharapkan peneliti selanjutnya agar menambah variabel dan menambah periode penelitian sehingga dapat memberikan sampel yang baik.

\section{Daftar Pustaka}

Alfina, I. T., Nurlaela, S., \& Wijayanti, A. (2018). The Influence of Profitability, Leverage, Independent Commissioner, and Company Size to Tax Avoidance. The 2nd International Conference on Technology, Education, and Social Science 2018, 2018(10), 102-106. https://ejurnal.unisri.ac.id/index.php/proictss/article/view/2201

Amaliyah, R., \& Rachmawati, N. A. (2019). Peran Komisaris Independen Dan Kualitas Audit Terhadap Penghindaran Pajak. 1.

Anggraeni, T., \& Oktaviani, R. M. (2021). Dampak Thin Capitalization, Profitabilitas, Dan Ukuran Perusahaan Terhadap Tindakan Penghindaran Pajak. Jurnal Akuntansi Dan Pajak, 21(02), 390-397. https://doi.org/10.29040/jap.v21i02.1530

Arianandini \& Ramantha. (2018). Pengaruh Profitabilitas, Leverage, dan Kepemilikan Institusional pada Tax Avoidance. Journal of Chemical Information and Modeling, 53(9), 1689-1699.

Darma, R., Tjahjadi, Y. D. J., \& Mulyani, S. D. (2019). Pengaruh Manajemen Laba, Good Corporate Governance, Dan Risiko Perusahaan Terhadap Tax Avoidance. Jurnal Magister Akuntansi Trisakti, 5(2), 137. https://doi.org/10.25105/jmat.v5i2.5071

Eksandy, A. (2017). Pengaruh Komisaris Independen, Komite Audit, dan Kualitas Audit terhadap Penghindaran Pajak (Tax Avoidance) (Studi Empiris Pada Sektor Industri Barang Konsumsi yang terdaftar di Bursa Efek Indonesia Periode 2010-2014). COMPETITIVE Jurnal Akuntansi Dan Keuangan, 1(1), 1. https://doi.org/10.31000/competitive.v1i1.96

Hanlon, M., \& Heitzman, S. (2010). A review of tax research. Journal of Accounting and Economics, 50(2-3), 127-178. https://doi.org/10.1016/j.jacceco.2010.09.002

Irianto, B. S., Sudibyo, Y. A., \& Wafirli, A. (2017). The Influence of Profitability, Leverage, Firm Size and Capital Intensity Towards Tax Avoidance. International Journal of Accounting and Taxation, 5(2), 33-41. https://doi.org/10.15640/ijat.v5n2a3

Jensen, M. C., \& Meckling, W. H. (1976). Theory of the Firm: Managerial Behavior, Agency Costs and Ownership Structure. 3, 305-360.

Kimsen, Kismanah, I., \& Masitoh, S. (2019). Profitability, Leverage, Size of Company Towards Tax Avoidance. JIAFE (Jurnal Ilmiah Akuntansi Fakultas Ekonomi), 4(1), 29-36. https://doi.org/10.34204/jiafe.v4i1.1075

Krisna, A. M. (2019). Pengaruh Kepemilikan Institusional dan Kepemilikan Manajerial pada Tax Avoidance dengan Kualitas Audit sebagai Variabel Pemoderasi. Jurnal Ekonomi, Bisnis Dan Akuntansi, 18(2), 82-91.

Mahdiana, M. Q., \& Amin, M. N. (2020). Pengaruh Profitabilitas, Leverage, Ukuran Perusahaan, Dan Sales Growth Terhadap Tax Avoidance. Jurnal Akuntansi Trisakti, 7(1), 127. https://doi.org/10.25105/jat.v7i1.6289

Masrullah, Mursalim, \& Su'un, M. (2018). Pengaruh Kepemilikan Institusional, Komisaris Independen, Leverage dan Sales Growth terhadap Tax Avoidance pada Perusahaan Manufaktur di Bursa Efek Indonesia. 16(2), 142-165.

Pratiwi, N. P. D., Mahaputra, I. N. K. A., \& Sudiartana, I. M. (2020). Pengaruh Financial Distress, Leverage dan Sales Growth terhadap Tax Avoidance Pada Perusahaan Manufaktur yang Terdaftar di BEI Tahun 2016. Jurnal Kharisma, 2(1), 202-211.

Pratomo, D., \& Rana, R. A. (2021). Pengaruh Kepemilikan Institusional, Komisaris Independen dan Komite Audit terhadap Penghindaran Pajak. Paper Knowledge . Toward a Media

JURNAL ILMIAH KOMPUTERISASI AKUNTANSI Vol. 14, No. 2, Desember $2021: 297$ - 307 
History of Documents, 8(1), 12-26.

Putri, A. A., \& Lawita, N. F. (2019). Pengaruh Kepemilikan Institusional Dan Kepemilikan Manajerial Terhadap Penghindaran Pajak. Jurnal Akuntansi Dan Ekonomika, 9(1), 87-104. https://doi.org/10.32795/widyaakuntansi.vli1.249

Putri, V. R., \& Putra, B. I. (2017). Pengaruh Leverage, Profitability, Ukuran Perusahaan Dan Proporsi Kepemilikan Institusional Terhadap Tax Avoidance. Jurnal Manajemen Dayasaing, 19(1), 1. https://doi.org/10.23917/dayasaing.v19i1.5100

Santoso, Y. I. (2020). Akibat penghindaran pajak, Indonesia merugi Rp 68,7 triliun per tahun. Kontan.Co.Id. https://newssetup.kontan.co.id/news/akibat-penghindaran-pajak-indonesiamerugi-rp-687-triliun-per-tahun

Sari, N., Luthan, E., \& Syafriyeni, N. (2020). Pengaruh Profitabilitas, Leverage, Komisaris Independen, Kepemilikan Institusional, dan Ukuran Perusahaan terhadap Penghindaran Pajak pada Perusahaan Manufaktur yang Terdaftar di Bursa Efek Indonesia pada Tahun 2014-2018. Jurnal Ilmiah Universitas Batanghari Jambi, 20(2), 376. https://doi.org/10.33087/jiubj.v20i2.913

Triyanti, N. W., Titisari, K. H., \& Dewi, R. R. (2020). Pengaruh Profitabilitas, Size, Leverage, Komite Audit, Komisaris Independen dan Umur Perusahaan terhadap Tax Avoidance. Jurnal Ilmiah Universitas Batanghari Jambi, 20(1), 113. https://doi.org/10.33087/jiubj.v20i1.850

Wijayanti, Y. C., \& Merkusiwati, N. K. L. A. (2017). Pengaruh Proporsi Komisaris Independen, Kepemilikan Institusional, Leverage, Dan Ukuran Perusahaan Pada Penghindaran Pajak. EJurnal Akuntansi, 20(1), 699-728.

Yulyanah, \& Kusumastuti, S. Y. (2019). Tax Avoidance Pada Perusahaan Manufaktur Sektor Industri Barang Dan Konsumsi Sub Sektor Makanan Dan Minuman. Media Ekonomi, 27(1), 17-36. doi: http://dx.doi.org/10.25105/me.v27i1.5284 